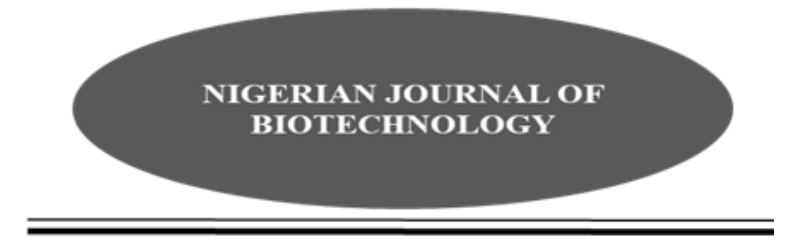

\title{
Effects of two rhizobacteria inoculants on maize growth performance at different concentrations of glyphosate.
}

\author{
${ }^{1}$ Akintokun, P.O., ${ }^{2}$ Ezaka, E., ${ }^{3}$ Akintokun A.K. and ${ }^{2}$ Oyedele O.A. \\ ${ }^{1}$ Department of Plant physiology and Crop Production, Federal University of Agriculture, Abeokuta \\ ${ }^{2}$ Institute of Agricultural Research and Training Moor Plantation, Ibadan \\ ${ }^{3}$ Department of Microbiology, Federal University of Agriculture Abeokuta
}

\begin{abstract}
The use of Rhizobacteria as biofertilizer is on the increase due to the ability of some of the bacteria to solubilize some insoluble essential nutrients in the soil and produce phytohormones necessary for plant growth. The effectiveness of two plant growth promoting rhizobacteria (Bacillus cereus and Pseudomonas aeruginosa) in plant growth promotion at different concentrations of glyphosate were evaluated. Some agronomic parameters such as plant height, size of girth, number of leaves on the screen house and field were measured and recorded. The results of the effects of $\boldsymbol{P}$. aeruginosa on the height of maize at different concentrations showed that the plants inoculated with the isolates and planted on the soil without glyphosate (control) recorded the highest height on the $2^{\text {nd }}(34.9 \mathrm{~cm}), 4^{\text {th }}(52.45 \mathrm{~cm})$, $6^{\text {th }}(61.17 \mathrm{~cm})$ and $8^{\text {th }}(66.25 \mathrm{~cm})$ weeks after planting, when compared to those planted on the soil spiked with different concentrations of glyphosate. The effects of the isolates on the size of girth of maize on the soil spiked with different concentrations of glyphosate showed the highest girth size on the soil inoculated with $P$. aeruginosa eight weeks after planting (8 WAP) with a girth size of $2.0 \mathrm{~cm}$ and least at $14.4 \mathrm{mg} / \mathrm{ml}$ of glyphosate with a girth size of $1.2 \mathrm{~cm}$ at 8 weeks after planting. Similar trend was observed on the soil inoculated with $B$. cereus (without glyphosate) with the highest girth in the $2^{\text {nd }}$ and $4^{\text {th }}$ WAP $(1.02$ and $1.42 \mathrm{~cm}$, respectively). The results of our field studies showed no significant difference $\quad(P \leq 0.05)$ in the height and number of leaves of the maize at different treatments and time (weeks after planting). Similar trend was observed $\mathbf{i} n$ the yield of maize. This study has shown that these isolates can be useful as biofertilizers especially in the absence or at low concentration of glyphosate.
\end{abstract}

Keywords: Rhizobacteria, maize, Inoculants, Plant-growth-promotion.

Corresponding author email: emma_ezaka@yahoo.com, +2348063289776

Introduction

Maize is widely grown for its grain and fodder. The grains are used in various ways by humans. Different parts of maize can be used in the production of different types of food for humans and animals. It is used in the production of feed for animals and for different industrial uses, while it is commonly used as source of food 
in under developed countries (IITA, 2001). Although maize is one of the major crops used as sources of feed for livestock, it is as well one of the commonest foods in every house hold in Nigeria. There is an increase in maize yield due to the release of improved cultivars but still maize faces a lot of problems such as weeds and other pests, as well as low soil fertility resulting from continuous cropping and excessive use of agrochemicals. The activities of some essential soil organisms which can enhance maize yield through solubilization of insoluble nutrients in the soil which boasts nutrient availability for maize may be affected by agrochemicals such as glyphosate. The continuous spread of herbicides interferes with the plant growth promoting activities of rhizobacteria and hence reduces their efficiency in enhancing plant growth promotion leading to low soil fertility and poor yield of maize (Ezaka et al. 2018). The continuous utilization of herbicides in the production of maize will not only affect the productivity of maize but can as well affect its quality and may likely cause environmental pollution. Therefore, the utilization of plant growth promoting rhizobacteria will reduce the over dependence on chemical fertilizer and as well enhance the breakdown of glyphosate and its by products, reduce contamination of soil and plant products by glyphosate. Hence, this work is therefore designed to assess the effects of plant growth promoting rhizobacteria inoculants on maize grown at different concentrations of glyphosate.

\section{Materials and methods}

\section{Microorganisms and culture condition}

Two plant growth promoting bacteria initially identified as Bacillus cereus and Pseudomonas aeruginosa isolated from soil rhizosphere of yellow and white maize were used for this work (Akintokun et al, 2019). The isolates were stored on agar slants for further use.

Plant growth Studies in the Screen house and Field using the isolates Experimental site and location
Screen house: The screen house studies were conducted at the Research screen house of the National quarantine center Moor Plantation, Ibadan while the soil sample for the studies were collected from I.A.R \& T, Ibadan. Five kilograms of soil was weighed, sieved and filled in forty eight perforated plastic pots. All treatments were arranged and laid in Complete Randomized Design (CRD) with three replicates. The physicochemical parameters of the soil used for the study were investigated according to the method of Baeta et al, (2006).

\section{Spiking of Soil with different Concentrations of glyphosate}

Five kilograms of soil were weighed into plastic pots. Different concentrations (3.1, 7.2 and $14.4 \mathrm{mg} / \mathrm{ml}$ ) of the herbicide (forceup) was mixed very well with water and spiked on the soil samples.

\section{Preparation of bacteria Inoculum}

The selected isolates were inoculated in $50 \mathrm{ml}$ conical flask containing $25 \mathrm{ml}$ of prepared and sterilized nutrient broth and incubated at $30^{\circ} \mathrm{C}$ in an orbital incubator shaker for $24 \mathrm{~h}$. After incubation, the culture was spinned at $4000 \mathrm{rpm}$ for 20 mins. The cells were harvested and washed with normal saline. In order to ensure equal cell size, the cells were diluted to 0.5 Mcfarlands Standard to give an approximate cell density of $1.5 \times 10^{8} \mathrm{Cfu} / \mathrm{ml}$ (Akintokun et al.,2019).

\section{Seed sterilization and Inoculation}

Maize Seeds (Swan 1) were surface-sterilized with $70 \%$ ethanol and $2 \%$ sodium hypo chloride for 5 mins and then washed with sterile distilled water. The surface- sterilized seeds were inoculated with the isolates by soaking in the respective bacterial suspension for 45 mins.

Experimental Design and treatments: Complete randomized design and complete randomized block design (plot size of $2 \times 3 \mathrm{~m}$ ) with three replicates were used for screen house and field studies. The following treatments were used: 


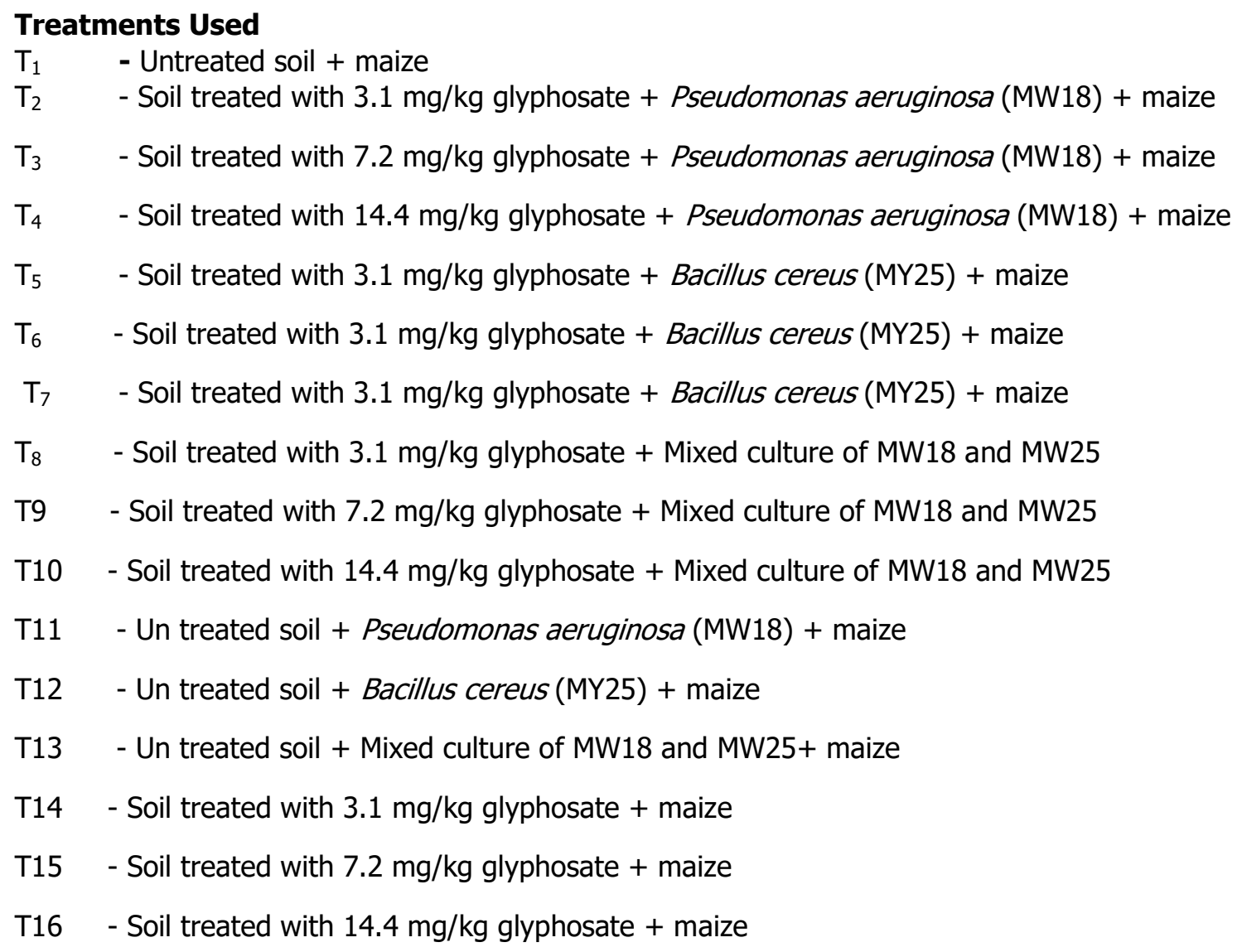

Planting of Inoculated Seeds and Determination of growth Parameters

Maize Seeds (SWAN 1 yellow) were inoculated by soaking them in the respective bacterial suspension. Four seeds were planted per pot in the screen house and later thinned to 2 plants per pot after two weeks. Growth parameters such as height, girth size and number of leaves were measured at 2, 4 and 6 weeks after planting. The plant heights were measured with meter rule while girth size was determined with vernier caliper.

\section{Field Experiment:}

The field experiments were carried out at the research farm of the Institute of Agriculture Research and Training, Moor Plantation, Ibadan, during the 2017 farming seasons, with the experiment laid out in a complete randomized block design with three replicates and plot size of $2 \times 3 \mathrm{~m}$. The experiment was conducted on a plot of land located at a latitude $7^{\circ} 22.701^{1} \mathrm{~N}$ and longitude $3^{\circ} 50.308^{1} \mathrm{E}, \quad$ in the rainforest ecological zone of the South west, Nigeria.

Land preparation and application of herbicides for field studies

The lands were cleared and tilled prior to application of glyphosate (forceup). Six hundred milliliter $(600 \mathrm{ml})$ of water containing $3.1,7.2$ and $14.4 \mathrm{mg} / \mathrm{ml}$ of glyphosate corresponding to half -field application rate and twice the field application rate were spiked on each of the $2 \times 3$ $\mathrm{m}$ plots and were allowed to stand for 7 days before planting. The maize seeds (SWAN 1 yellow) were sown on the plots after 7 days of herbicide application. This was followed by spiking of the bacteria suspension on the field.

\section{Planting of Inoculated Seeds}

Maize Seeds (SWAN 1 yellow) were inoculated by soaking them in the respective bacterial suspension, and 2-3 seeds were planted per hole on a $2 \times 3 \mathrm{~cm}$ plot at a planting distance of 75 $\mathrm{cm}$ between rows and intra row distance of $25 \mathrm{~cm}$ 
and were thinned to one plant per hole after two weeks. Uninoculated seeds were also planted as control.

Measurement of Physicochemical properties of the soil and growth parameters of the maize

The physicochemical parameters of the soil used for the study before and after planting are presented on Table 1.The results of the chemical parameters were not significantly different except for iron (Fe) whose values were significantly higher when compared to the control. Growth parameters such as the leaf count, height of the maize plant, girth size and the maize yield at harvest were collected. These data were collected three weeks after planting (WAP) the maize seeds and then seven weeks (7 WAP) and 10 weeks (10 WAP) after planting. The girth was measured using vernier caliper while the yield of the maize planted in each of the experimental plots was determined by harvesting and weighing the cobs in each of the experimental plots. The mean weights of all the cobs harvested from the replicate plots were then calculated to determine the yield of each of the experimental plots.

\section{Results}

Table 1: Physicochemical parameters of the soil before and after planting

\begin{tabular}{|c|c|c|c|c|c|}
\hline Parameters & $\begin{array}{l}\text { Initial soil sample } \\
\text { (Pre-field) }\end{array}$ & $3.1 \mathrm{mg} / \mathrm{ml}$ & $\begin{array}{l}7.2 \mathrm{mg} / \mathrm{ml} \\
\text { (Post field) }\end{array}$ & $14.4 \mathrm{mg} / \mathrm{ml}$ & Untreated soil \\
\hline pH & 6.19 & 5.98 & 5.91 & 6.08 & 5.94 \\
\hline $\mathrm{Ca}(\mathrm{mol} / \mathrm{kg})$ & 1.79 & 2.54 & 2.32 & 1.88 & 2.52 \\
\hline $\mathrm{Mg}(\mathrm{mol} / \mathrm{kg})$ & 0.76 & 0.96 & 1.15 & 1.06 & 1.49 \\
\hline$K(\mathrm{~mol} / \mathrm{kg})$ & 0.22 & 0.14 & 0.20 & 0.19 & 0.17 \\
\hline $\mathrm{Na}(\mathrm{mol} / \mathrm{kg})$ & 0.32 & 0.34 & 0.38 & 0.66 & 0.34 \\
\hline $\mathrm{H}^{+}$ & 0.10 & 0.11 & 0.11 & 0.11 & 0.11 \\
\hline CEC & 3.18 & 7.09 & 4.17 & 3.89 & 4.32 \\
\hline \% B. Sat. & 96.84 & 98.43 & 97.25 & 97.28 & 97.39 \\
\hline SAR & 0.06 & 0.03 & 0.05 & 0.11 & 0.05 \\
\hline$\%$ ESP & 10.07 & 4.83 & 9.06 & 17.01 & 7.80 \\
\hline B (ppm) & 0.04 & 0.02 & 0.02 & 0.03 & 0.01 \\
\hline$P($ ppm $)$ & 3.07 & 5.08 & 6.47 & 7.12 & 12.80 \\
\hline$\%$ TC & 0.97 & 0.91 & 1.01 & 0.67 & 0.76 \\
\hline$\%$ TN & 0.06 & 0.07 & 0.04 & 0.05 & 0.05 \\
\hline Cu (ppm) & 0.80 & 0.67 & 1.24 & 1.09 & 0.63 \\
\hline
\end{tabular}




$\begin{array}{llllll}\text { Fe (ppm) } & 99.86 & 117.56 & 124.7 & 156.08 & 137.64 \\ \text { Mn (ppm) } & 35.17 & 46.05 & 35.26 & 23.65 & 1.62 \\ \text { Zn (ppm) } & 1.04 & 2.11 & 1.91 & 9.7 & 2.05\end{array}$

Effects of the bacterial inoculants on the growth of the maize in the screen house

The effects of the isolates when used singly and mixed were evaluated; the result showed no significant difference $(P \leq 0.05)$ in their effects to the growth of the maize (Fig. 1). The maize plant inoculated with Bacillus cereus recorded the highest height $(69.8 \mathrm{~cm})$ after eight weeks of planting, followed by Pseudomonas aeruginosa $(66.3 \mathrm{~cm})$ and the mixed culture of $P$. aeruginosa and $B$. cereus $(62.2 \mathrm{~cm})$ while the least was observed in the control $(61.7 \mathrm{~cm})$. The results of the plant girth showed that the plants inoculated with the mixed culture of $B$. cereus and $P$. aeruginosa recorded the highest girth size $(1.8 \mathrm{~cm})$ followed by $P$. aeruginosa $(1.6 \mathrm{~cm})$, then $B$. cereus $(1.52 \mathrm{~cm})$ and the least size was observed in the control $(1.4 \mathrm{~cm})$ (Fig. 2). A similar trend was observed in the leaf area in which the plant inoculated with the mixed culture and $P$. aeruginosa had the highest leaf area after 8 weeks of planting and the least was recorded in B. cereus treatment (Fig. 3).

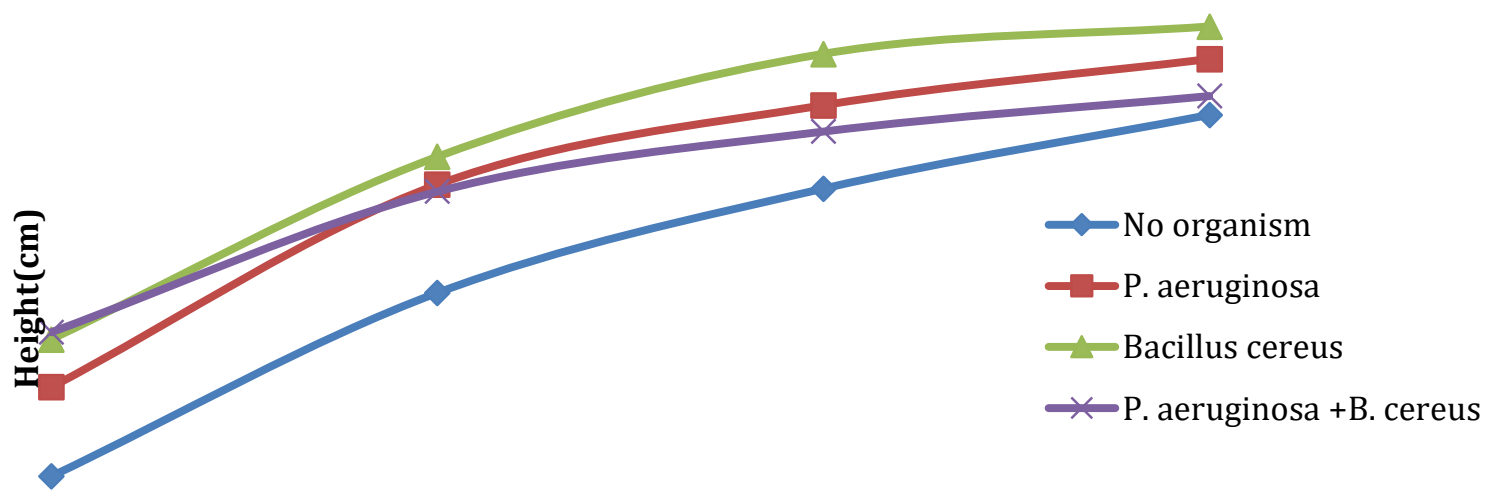

Fig 1: Effects of the inoculants on the heights of the maize plants 


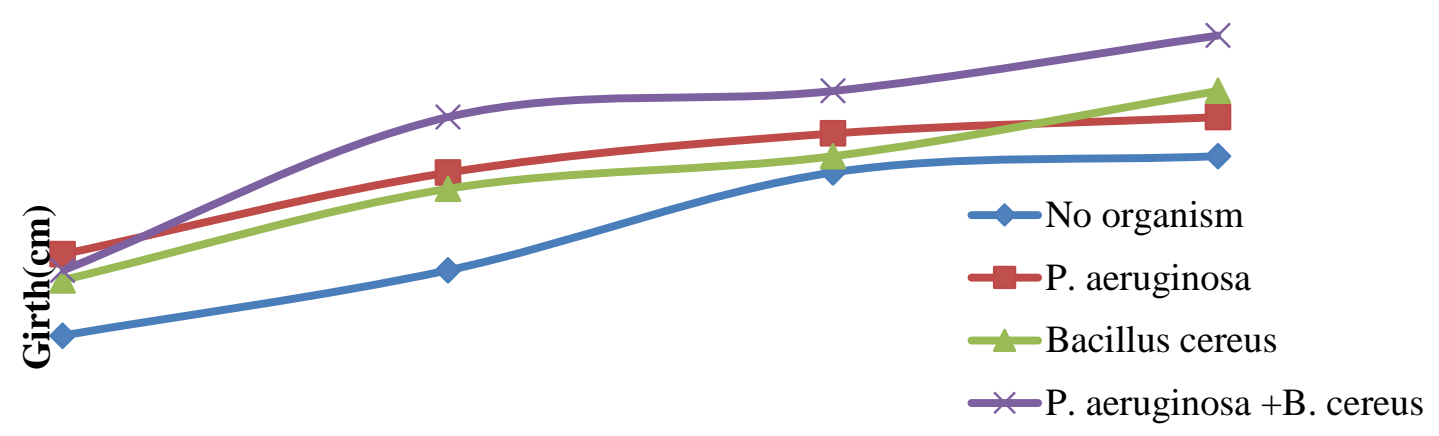

Fig 2: Effects of the inoculants on the maize girth sizes

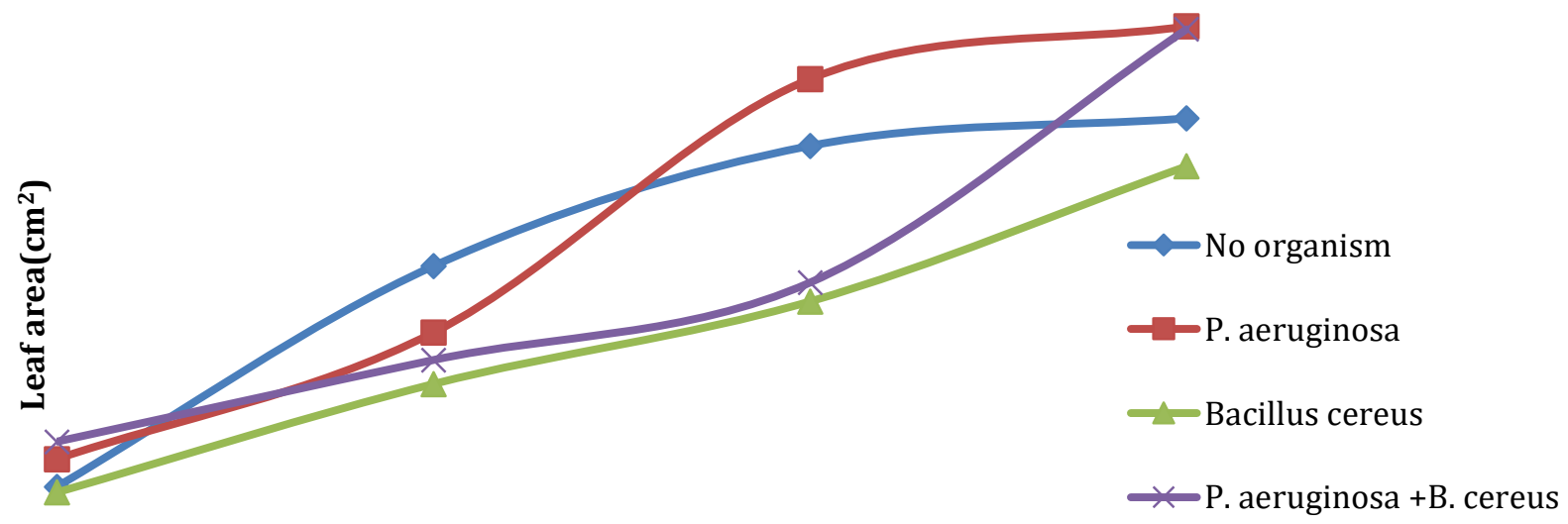

Fig 3: Effects of the inoculants on the maize leaf areas 
Effects of the inoculants on the growth of the maize at different concentrations of glyphosate.

The results of the effects of the bacterial inoculants on the heights of the maize plants from the soil spiked with different concentrations of glyphosate are presented i $\mathrm{n}$ Table 2 . The results showed the plants inoculated with the isolates and planted on the soil without glyphosate (control) recorded the highest height after $8 \quad(66.25 \mathrm{~cm})$ weeks of planting when compared to those planted on the soil spiked with the different concentrations of glyphosate. At $3.1 \mathrm{mg} / \mathrm{ml}$ of glyphosate, the heights of the maize were 29.08 , $34.0,59.66$ and $60.45 \mathrm{~cm}$ at the $2^{\text {nd }}, 4$ th, $6^{\text {th }}$ and $8^{\text {th }}$ weeks, respectively. At week two after planting, the least height was recorded from the soil spiked with $7.2 \mathrm{mg} / \mathrm{ml}$ glyphosate with a maize height of $22.53 \mathrm{~cm}$ while at weeks four, six and eight, the least was recorded from the soil spiked with $14.4 \mathrm{mg} / \mathrm{ml}$ glyphosate with maize heights of $30.4,34.66$ and $45.2 \mathrm{~cm}$, respectively. The results of the effect of $B$. cereus on the heights of the maize at different glyphosate concentrations were not significantly different $(P \leq 0.05)$ at different weeks after planting within the treatments, but all were significantly different $(\mathrm{P} \leq 0.05)$ from the control. The control also recorded the highest maize height at all the weeks after planting with the plant heights of $33.45,55.5,66.8$ and $70.0 \mathrm{~cm}$ for the $2^{\text {nd }}, 4^{\text {th }}, 6^{\text {th }}$ and $8^{\text {th }}$ weeks after planting, respectively. The plant heights from the soil spiked with $3.1 \mathrm{mg} / \mathrm{ml}$ of glyphosate at $2^{\text {nd }}, 4^{\text {th }}$, $6^{\text {th }}$ and $8^{\text {th }}$ weeks after planting were 26.37 , $35.56,53.4$ and $58.8 \mathrm{~cm}$, respectively. For the soil spiked with $7.2 \mathrm{mg} / \mathrm{ml}$ glyphosate, $\mathrm{t}$ he maize heights at the 2nd, 4th, 6th and 8th weeks after planting were $21.27 \mathrm{~cm}, 38.7 \mathrm{~cm}, 39.3 \mathrm{~cm}$ and $46.67 \mathrm{~cm}$, respectively, while for those spiked with $14.4 \mathrm{mg} / \mathrm{ml}$ glyphosate the heights were respectively $23.3 \mathrm{~cm}, 30.58 \mathrm{~cm}$, $43.3 \mathrm{~cm}$ and $49.16 \mathrm{~cm}$.

The effects of the isolates on girth size of the maize from the soils spiked with the different concentrations of glyphosate are shown in figures 4-6. The highest girth size was recorded at $3.1 \mathrm{mg} / \mathrm{ml}$ glyphosate from the soil inoculated with $P$. aeruginosa eight weeks after planting (8 WAP) while the least was at $14.4 \mathrm{mg} / \mathrm{ml}$ of glyphosate (Fig. 4). Similar trend was observed from the soil inoculated with B. cereus (without glyphosate) with the highest girth at the $2^{\text {nd }}$ and $4^{\text {th }}$ WAP (1.02 and $1.42 \mathrm{~cm}$, respectively) (Fig. 5). At the 6th and 8th WAP, the highest girth was recorded from the soil spiked with 3.1 $\mathrm{mg} / \mathrm{ml}$ with girth sizes of 1.65 and $1.8 \mathrm{~cm}$, respectively. The least was also from the soil amended with $14.4 \mathrm{mg} / \mathrm{ml}$ with girth sizes of $0.73,0.78,1.23$ and $1.42 \mathrm{~cm}$ at 2, 4, 6 and 8 WAP, respectively (Fig. 6). The results were not significantly different $(P \leq 0.05)$ at different concentrations and weeks. The effects of the mixed culture of the isolates on the girth size were also not significantly different at different concentrations and weeks.

Table 2: Effects of glyphosate and microbial inoculants on the height of the maize plants

\begin{tabular}{lllll}
\hline TREATMENT & 2 WAP & 4 WAP & 6 WAP & 8 WAP \\
\hline T 1 & $29.08 \pm 2.00^{\mathrm{a}}$ & $34.00 \pm 0.80^{\mathrm{a}}$ & $59.66 \pm 1.00 \mathrm{a}$ & $60.45 \pm 0.57^{\mathrm{a}}$ \\
T 2 & $22.53 \pm 0.04^{\mathrm{bd}}$ & $38.52 \pm 0.20^{\mathrm{b}}$ & $41.20 \pm 0.75^{\mathrm{b}}$ & $52.95 \pm 0.10^{\mathrm{b}}$ \\
T 3 & $23.50 \pm 0.55^{\mathrm{b}}$ & $30.50 \pm 0.88^{\mathrm{c}}$ & $34.66 \pm 0.16^{\mathrm{c}}$ & $45.23 \pm 3.50^{\mathrm{c}}$ \\
T 4 & $26.37 \pm 0.05^{\mathrm{c}}$ & $35.56 \pm 0.09^{\mathrm{a}}$ & $53.43 \pm 0.20^{\mathrm{d}}$ & $58.77 \pm 0.57^{\mathrm{a}}$
\end{tabular}




\begin{tabular}{|c|c|c|c|c|}
\hline T 5 & $21.27 \pm 1.02^{d}$ & $38.70 \pm 0.81^{b}$ & $43.80 \pm 0.06^{b}$ & $46.67 \pm 0.40^{c}$ \\
\hline T 6 & $23.30 \pm 0.11^{b}$ & $30.58 \pm 2.01^{c}$ & $43.30 \pm 1.00^{b}$ & $49.16 \pm 0.92^{b c}$ \\
\hline T 7 & $35.03 \pm 0.32^{\mathrm{e}}$ & $45.46 \pm 0.00^{d}$ & $60.80 \pm 0.31^{a}$ & $63.00 \pm 0.03^{a}$ \\
\hline T 8 & $38.63 \pm 0.05^{f}$ & $40.70 \pm 2.00^{\mathrm{bd}}$ & $65.10 \pm 0.91^{\mathrm{e}}$ & $69.60 \pm 0.57^{d}$ \\
\hline Т 9 & $30.68 \pm 0.33^{a}$ & $38.52 \pm 0.03^{b}$ & $43.02 \pm 0.11^{b}$ & $45.50 \pm 1.04^{c}$ \\
\hline T 10 & $20.40 \pm 1.03^{d}$ & $40.55 \pm 4.00 \mathrm{bd}$ & $52.05 \pm 2.02^{d}$ & $62.20 \pm 0.88^{a}$ \\
\hline Т 11 & $34.90 \pm 0.10^{e}$ & $51.70 \pm 0.66^{e}$ & $61.17 \pm 0.31^{\mathrm{ae}}$ & $66.25 \pm 1.06^{\mathrm{ad}}$ \\
\hline T 12 & $36.25 \pm 2.00^{e}$ & $55.45 \pm 0.77^{f}$ & $66.80 \pm 3.00^{e}$ & $69.80 \pm 0.13^{d}$ \\
\hline T 13 & $36.55 \pm 1.33^{\mathrm{e}}$ & $51.60 \pm 0.61^{\mathrm{e}}$ & $58.30 \pm 0.33^{a}$ & $62.40 \pm 1.11^{a}$ \\
\hline T14 & $20.10 \pm 0.75^{d}$ & $32.15 \pm 0.03 c$ & $40.50 \pm 1.06^{\mathrm{bc}}$ & $51.38 \pm 0.28^{b}$ \\
\hline T15 & $20.63 \pm 1.20^{d}$ & $30.60 \pm 1.20^{c}$ & $39.83 \pm 0.90^{\mathrm{bc}}$ & $48.29 \pm 0.14^{b c}$ \\
\hline T16 & $19.70 \pm 0.08^{d}$ & $25.22 \pm 3.00^{\mathrm{g}}$ & $36.40 \pm 0.01^{b c}$ & $40.41 \pm 2.00^{d}$ \\
\hline
\end{tabular}

Means with the same letter within a column are not significantly different $(\mathrm{P} \leq 0.05)$

**T1- $3.1 \mathrm{mg}$ of glyphosate $/ \mathrm{ml}+P$. aeruginosa, T2- $7.2 \mathrm{mg} / \mathrm{ml}+P$. aeruginosa, T3- $14.4 \mathrm{mg} / \mathrm{ml}+P$. aeruginosa, T4- $3.1 \mathrm{mg} / \mathrm{ml}+B$. cereus, T5- $7.2 \mathrm{mg} / \mathrm{ml}+$ B. cereus, T6- $14.4 \mathrm{mg} / \mathrm{ml}+B$. cereus, T7- 3.1 $\mathrm{mg} / \mathrm{ml}+$ Mixed culture of $B$. cereus/P. aeruginosa, T8- $7.2 \mathrm{mg} / \mathrm{ml}+$ mixed culture, T9- $14.4 \mathrm{mg} / \mathrm{ml}+$ Mixed culture, T10- unsprayed soil, T11- $P$. aeruginosa, T12- B. cereus, T13- mixed culture of $B$. cereus/ $P$. aeruginosa ，T14- $3.1 \mathrm{mg} / \mathrm{ml}$ only, T15- $7.2 \mathrm{mg} / \mathrm{ml}$ only, T16- $14.4 \mathrm{mg} / \mathrm{ml}$ only.

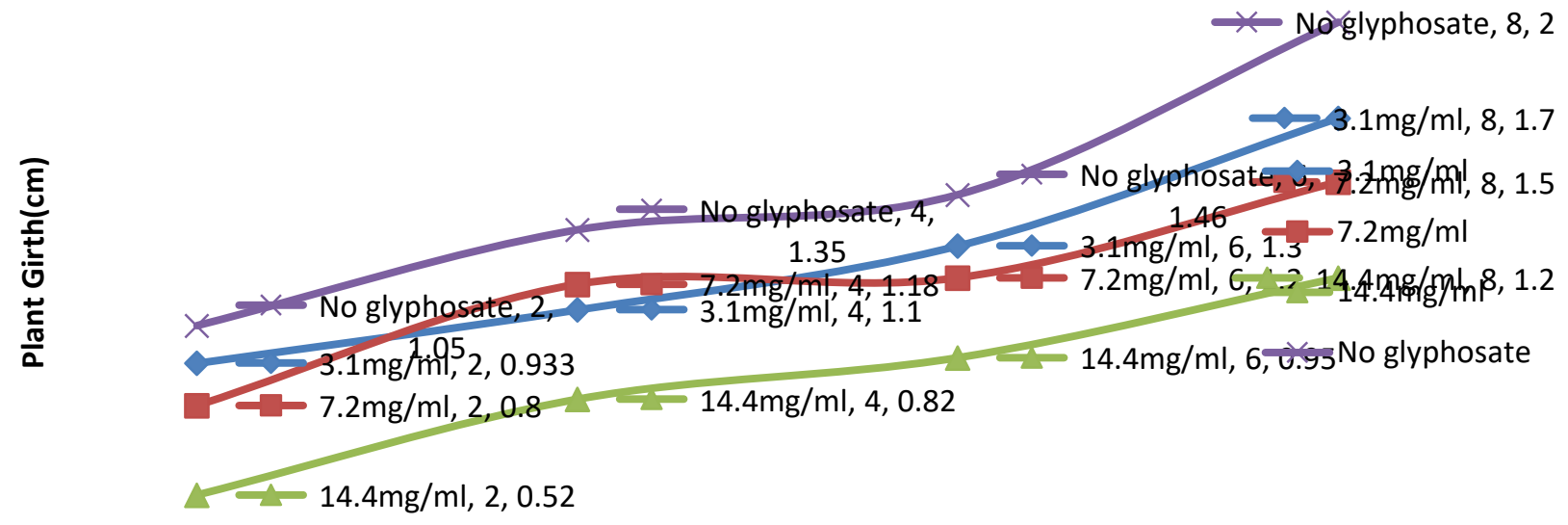

Weeks after planting (WAP)

Fig. 4: Effects of Pseudomonas aeruginosa on the maize girth from the soil spiked with $3.1,7.2$ and $14.4 \mathrm{mg} / \mathrm{ml}$ of glyphosate 


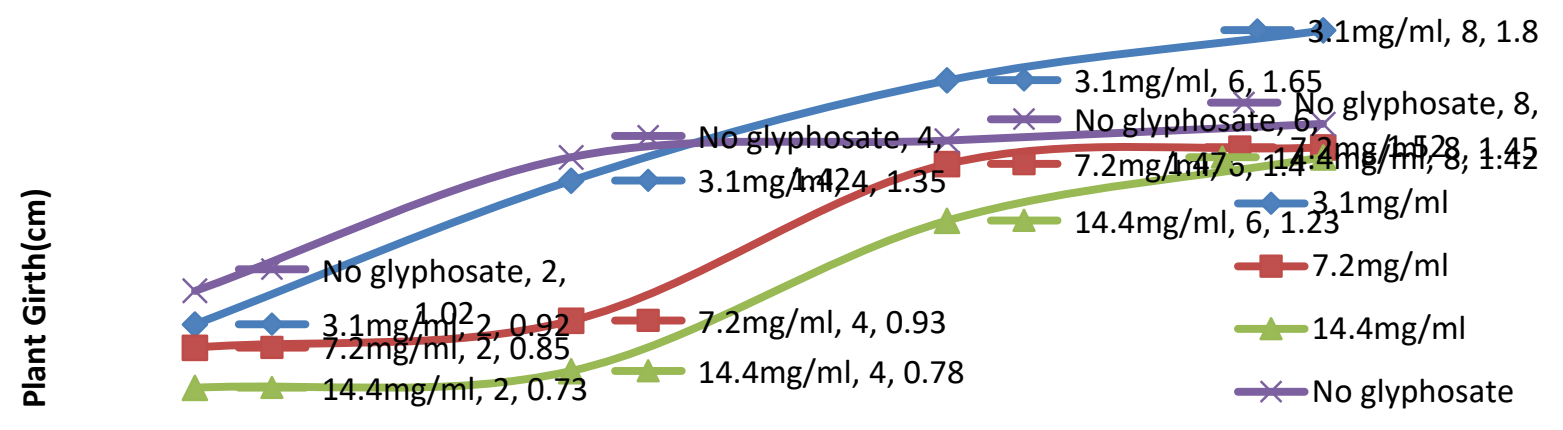

\section{Weeks after planting (WAP)}

Fig. 5: Effects of Bacillus cereus on the maize girth from the soil spiked with $3.1,7.2$ and $14.4 \mathrm{mg} / \mathrm{ml}$ of glyphosate

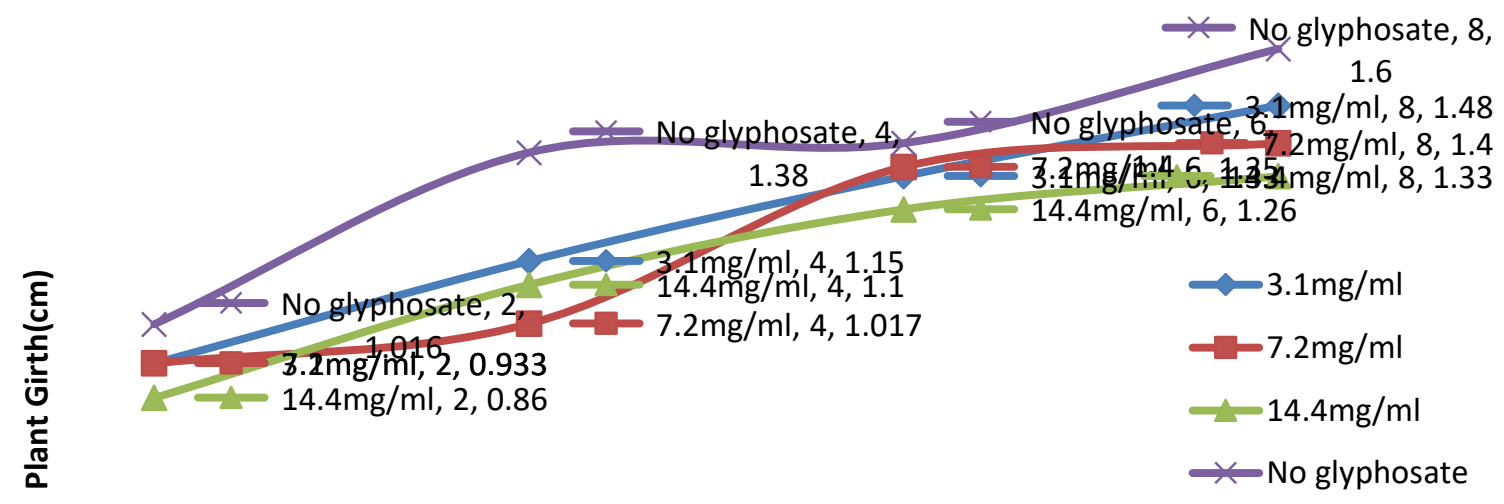

Weeks After planting (WAP)

Fig. 6: Effects of mixed culture of $P$. aeruginosa and $B$. cereus $s$ on the maize girth from the soil spiked with $3.1,7.2$ and $14.4 \mathrm{mg} / \mathrm{ml}$ of glyphosate 


\section{Results of the field trials}

Effects of glyphosate and microbial inoculants on growth of the maize plants $i \quad n$ the field

The results of the effects of microbial inoculants on the height of the maize plants are presented $i$ $\mathrm{n}$ Table 4. At 3 WAP, the plot treated with a mixed culture of $P$. aeruginosa and $B$. cereus recorded the highest height $(35.33 \mathrm{~cm})$ while the least height was recorded from plot spiked with $14.4 \mathrm{mg} / \mathrm{ml}$ glyphosate $+P$. aeruginosa. The plot treated with $14.4 \mathrm{mg} / \mathrm{ml}$ of glyphosate $+B$. cereus recorded the highest maize height
$(96.25 \mathrm{~cm})$ at 7 WAP while the least was from the plot treated with $7.2 \mathrm{mg} / \mathrm{ml}+$ Mixed cultures of the isolates $(48.80 \mathrm{~cm})$. At 10 WAP, the soil treated with $7.2 \mathrm{mg} / \mathrm{kg}+P$. aeruginosa had the highest maize height while the untreated soil had the least.

The mean number of leaves at 3 WAP ranged between 5.0 and 6.3 while at 7 WAP it ranged between 7.00 and 10.80. Also at 10 WAP, it is within the range of 7.40 to 10.80 . The result is shown on Table 5.

Table: 4: Effects of glyphosate and microbial inoculants on the height of maize

\begin{tabular}{|c|c|c|c|}
\hline TREATMENT & $\begin{array}{l}3 \text { WAP } \\
\text { PLANT HEIGHT }(\mathrm{cm})\end{array}$ & $\begin{array}{l}7 \text { WAP } \\
\text { PLANT } \\
(\mathrm{cm})\end{array}$ & $\begin{array}{l}10 \text { WAP } \\
\text { PLANT } \\
(\mathrm{cm})\end{array}$ \\
\hline T 1 & $21.87 \pm 0.21^{a}$ & $85.00 \pm 0.05^{a}$ & $109.50 \pm 0.30^{a}$ \\
\hline Т 2 & $24.67 \pm 1.00^{\mathrm{ab}}$ & $82.50 \pm 2.00^{\mathrm{ab}}$ & $122.63 \pm 1.20^{\mathrm{b}}$ \\
\hline T 3 & $25.73 \pm 0.20^{\mathrm{ab}}$ & $87.50 \pm 0.68^{b}$ & $154.25 \pm 0.91^{c}$ \\
\hline T 4 & $18.97 \pm 0.50^{c}$ & $78.75 \pm 0.08^{c}$ & $126.25 \pm 4.20^{d}$ \\
\hline T 5 & $28.7 \pm 0.06^{b}$ & $89.50 \pm 0.50^{\mathrm{ab}}$ & $140.80 \pm 1.50^{\mathrm{e}}$ \\
\hline T 6 & $31.1 \pm 0.45^{d}$ & $96.25 \pm 0.11^{d}$ & $142.25 \pm 0.55^{\mathrm{e}}$ \\
\hline T 7 & $28.93 \pm 2.00^{b}$ & $81.50 \pm 4.0^{c}$ & $119.80 \pm 1.30^{f}$ \\
\hline Т 8 & $21.03 \pm 0.58^{a}$ & $48.80 \pm 0.55^{e}$ & $118.00 \pm 0.05^{f}$ \\
\hline Т 9 & $26.07 \pm 3.0^{a b}$ & $55.75 \pm 0.45^{\mathrm{ef}}$ & $106.20 \pm 0.60^{a}$ \\
\hline 10 & $25.17 \pm 0.28^{\mathrm{ab}}$ & $78.00 \pm 1.05^{c}$ & $130.00 \pm 3.20^{\mathrm{bd}}$ \\
\hline Т 11 & $27.3 \pm 4.00^{\mathrm{ad}}$ & $61.25 \pm 0.89^{g}$ & $112.13 \pm 0.07^{a f}$ \\
\hline Т 12 & $29.0 \pm 1.20^{\mathrm{b}}$ & $72.25 \pm 1.30^{g c}$ & $131.30 \pm 0.55^{\mathrm{bd}}$ \\
\hline Т 13 & $35.33 \pm 0.00^{e}$ & $70.00 \pm 0.85^{g c}$ & $117.38 \pm 0.01^{\text {af }}$ \\
\hline T14 & $20.05 \pm 0.2^{c}$ & $58.20 \pm 0.55^{e f}$ & $109.00 \pm 2.05^{a}$ \\
\hline T15 & $19.80 \pm 1.02^{c}$ & $42.00 \pm 2.55^{h}$ & $103.50 \pm 0.41^{\mathrm{g}}$ \\
\hline T16 & $18.85 \pm 0.71^{c}$ & $40.22 \pm 0.40^{h}$ & $104.00 \pm 0.06^{\mathrm{g}}$ \\
\hline
\end{tabular}


**T1- $3.1 \mathrm{mg} / \mathrm{ml}$ of glyphosate $+P$. aeruginosa, T2- $7.2 \mathrm{mg} / \mathrm{ml}+P$. aeruginosa, T3- $14.4 \mathrm{mg} / \mathrm{ml}+P$. aeruginosa, T4- $3.1 \mathrm{mg} / \mathrm{ml}+B$. cereus, T5- $7.2 \mathrm{mg} / \mathrm{ml}+B$. cereus, T6- $14.4 \mathrm{mg} / \mathrm{ml}+B$. cereus, T7- $3.1 \mathrm{mg} / \mathrm{ml}+$ Mixed culture of $B$. cereus/ $P$. aeruginosa, T8- $7.2 \mathrm{mg} / \mathrm{ml}+$ mixed culture, T9- $14.4 \mathrm{mg} / \mathrm{ml}$ + Mixed culture, T10- unsprayed soil, T11- $P$. aeruginosa, T12- $B$. cereus, T13- mixed culture of $B$. cereus/ $P$. aeruginosa, T14- $3.1 \mathrm{mg} / \mathrm{ml}$ only, T15- $7.2 \mathrm{mg} / \mathrm{ml}$ only, T16- $14.4 \mathrm{mg} / \mathrm{ml}$ only.

Table 5: Effects of glyphosate and microbial inoculants on the number of leaves of maize

\begin{tabular}{|c|c|c|c|}
\hline TREATMENT & $\begin{array}{l}3 \text { WAP } \\
\text { Number of leaves }\end{array}$ & $\begin{array}{l}7 \text { WAP } \\
\text { Number of leaves }\end{array}$ & $\begin{array}{l}10 \text { WAP } \\
\text { Number of leaves }\end{array}$ \\
\hline T 1 & $6.0 \pm 0.10 a$ & $9.75 \pm 2.10 \mathrm{a}$ & $9.75 \pm 0.04 a$ \\
\hline T 2 & $5.3 \pm 0.11 b$ & $9.75 \pm 0.30 a$ & $10.00 \pm 3.00 \mathrm{a}$ \\
\hline T 3 & $6.0 \pm 0.28 a$ & $10.38 \pm 0.60 a$ & $10.38 \pm 0.01 a$ \\
\hline T 4 & $5.0 \pm 0.02 b$ & $9.13 \pm 1.10 \mathrm{a}$ & $9.13 \pm 3.20 \mathrm{a}$ \\
\hline T 5 & $6.0 \pm 0.06 a$ & $9.25 \pm 4.00 \mathrm{a}$ & $9.80 \pm 0.50 a$ \\
\hline T 6 & $6.3 \pm 5.00 a$ & $9.30 \pm 1.06 a$ & $10.50 \pm 0.03 a$ \\
\hline T 7 & $6.3 \pm 2.10 \mathrm{a}$ & $10.80 \pm 2.50 a$ & $10.80 \pm 0.72 a$ \\
\hline T 8 & $5.3 \pm 0.08 b$ & $6.75 \pm 0.80 \mathrm{~b}$ & $8.25 \pm 0.22 b$ \\
\hline T 9 & $6.0 \pm 1.44 a$ & $7.50 \pm 0.01 a b$ & $8.63 \pm 0.35 a b$ \\
\hline T 10 & $5.0 \pm 0.45 b$ & $7.25 \pm 0.30 \mathrm{ab}$ & $10.00 \pm 0.01 a$ \\
\hline T 11 & $5.0 \pm 0.03 b$ & $7.00 \pm 2.00 a b$ & $7.40 \pm 3.40 c$ \\
\hline T 12 & $5.3 \pm 3.00 \mathrm{~b}$ & $8.63 \pm 0.32 a$ & $8.75 \pm 0.80 \mathrm{ab}$ \\
\hline T 13 & $6.0 \pm 0.54 a$ & $7.50 \pm 0.01 a b$ & $8.63 \pm 0.05 a b$ \\
\hline T14 & $5.00 \pm 0.4 b$ & $6.50 \pm 1.20 \mathrm{~b}$ & $7.00 \pm 0.51 c$ \\
\hline T 15 & $5.50 \pm 0.02 b$ & $6.00 \pm 0.44 b$ & $6.68 \pm 1.55 c$ \\
\hline T 16 & $5.00 \pm 2.01 b$ & $5.63 \pm 0.70 b$ & $6.0 \pm 0.05 d$ \\
\hline
\end{tabular}

Means with the same letters within a column are not significantly different $(P \leq 0.05)$

Key: T1- 3.1mg of glyphosate/ml $+P$. aeruginosa, T2- $7.2 \mathrm{mg} / \mathrm{ml}+P$. aeruginosa, T3- $14.4 \mathrm{mg} / \mathrm{ml}+P$. aeruginosa, T4- $3.1 \mathrm{mg} / \mathrm{ml}+B$. cereus, T5- $7.2 \mathrm{mg} / \mathrm{ml}+B$. cereus, T6- $14.4 \mathrm{mg} / \mathrm{ml}+B$. cereus, T7- $3.1 \mathrm{mg} / \mathrm{ml}+$ Mixed culture of $B$. cereus/ $P$. aeruginosa, T8- $7.2 \mathrm{mg} / \mathrm{ml}+$ mixed culture, T9- $14.4 \mathrm{mg} / \mathrm{ml}$ +Mixed culture, T10- unsprayed soil, T11- $P$. aeruginosa, T12- $B$. cereus, T13- mixed culture of $B$. cereus/ P. aeruginosa, T14- $3.1 \mathrm{mg} / \mathrm{ml}$ only, T15- $7.2 \mathrm{mg} / \mathrm{ml}$ only, T16- $14.4 \mathrm{mg} / \mathrm{ml}$ only. 
Effects of glyphosate and microbial inoculants on the yield of maize

The results of the effects of glyphosate and bacterial inoculants on the yield of the maize plants are presented i $\mathrm{n}$ Table 6 . The result of Stover weight was highest on the soil treated with $P$. aeruginosa (T11) only $(4.5 \mathrm{~kg})$ and least on the untreated soil (0.78). Soil treated with 3.1 $\mathrm{mg} / \mathrm{kg}$ and Bacillus cereus recorded the highest ear weight while the least was recorded on the untreated soil. The soil treated with 3.1 $\mathrm{mg} / \mathrm{kg}$ and Bacillus cereus also recorded the highest number of cobs (17.0) while the least value was recorded on the untreated soil and the soil treated with the mixed culture only (4.0). The highest cob weight was recorded from the Soil treated with $3.1 \mathrm{mg} / \mathrm{kg}$ and Bacillus cereus $(1.45 \mathrm{~kg})$ and the least was from the untreated soil $(0.35 \mathrm{~kg})$.

Table 6: Mean Effects of glyphosate and microbial inoculants on the yield of maize

\begin{tabular}{|c|c|c|c|c|c|}
\hline $\begin{array}{l}\text { TREAT- } \\
\text { MENT }\end{array}$ & $\begin{array}{l}\text { Stover } \\
\text { weight (kg) }\end{array}$ & $\begin{array}{l}\text { Ear } \\
\text { weight (kg) }\end{array}$ & No. of Cobs & $\begin{array}{l}\text { Cob } \\
\text { weight(kg) }\end{array}$ & $\begin{array}{l}\text { Grain } \\
\text { Weight(kg) }\end{array}$ \\
\hline Т 1 & $0.78 \pm 0.02^{\mathrm{a}}$ & $0.40 \pm 2.10^{a}$ & $4.00 \pm 0.40^{a}$ & $0.35 \pm 0.10^{a}$ & $0.15 \pm 0.00^{a}$ \\
\hline Т 2 & $2.40 \pm 0.00^{\mathrm{b}}$ & $1.33 \pm 0.00^{b}$ & $13.5 \pm 0.20^{b}$ & $1.00 \pm 0.50^{\mathrm{b}}$ & $0.40 \pm 0.20^{b}$ \\
\hline Т 3 & $2.40 \pm 0.30^{b}$ & $1.20 \pm 2.00^{b}$ & $12.0 \pm 0.25^{c}$ & $0.80 \pm 1.00^{b}$ & $0.38 \pm 0.10^{b}$ \\
\hline T 4 & $2.00 \pm 0.10^{c}$ & $0.90 \pm 0.05^{b}$ & $10.0 \pm 1.00^{\mathrm{cd}}$ & $0.55 \pm 0.05^{c}$ & $0.20 \pm 0.33^{a}$ \\
\hline T 5 & $2.48 \pm 0.11^{b}$ & $1.95 \pm 0.10^{\mathrm{d}}$ & $17.0 \pm 0.10^{\mathrm{e}}$ & $1.45 \pm 2.00^{b}$ & $0.77 \pm 1.10^{c}$ \\
\hline T 6 & $2.60 \pm 1.00^{b}$ & $1.25 \pm 0.90^{b}$ & $9.00 \pm 1.50^{d}$ & $1.00 \pm 1.20^{b}$ & $0.44 \pm 0.50^{b}$ \\
\hline T 7 & $1.35 \pm 0.50^{\mathrm{ab}}$ & $0.75 \pm 0.01^{c}$ & $8.00 \pm 0.02^{d}$ & $0.60 \pm 0.20^{c}$ & $0.33 \pm 0.40^{b}$ \\
\hline Т 8 & $0.80 \pm 0.10^{a}$ & $0.47 \pm 2.00^{a}$ & $4.50 \pm 0.15^{\mathrm{e}}$ & $0.25 \pm 0.10^{\mathrm{e}}$ & $0.11 \pm 0.10^{a}$ \\
\hline Т 9 & $1.40 \pm 0.40^{\mathrm{ab}}$ & $0.45 \pm 0.10^{a}$ & $6.00 \pm 0.00^{\text {de }}$ & $0.55 \pm 0.15^{c}$ & $0.30 \pm 0.00^{b}$ \\
\hline T 10 & $1.18 \pm 0.55^{\mathrm{a}}$ & $0.70 \pm 1.00^{c}$ & $4.00 \pm 0.10^{e}$ & $0.45 \pm 1.00^{c d}$ & $0.22 \pm 1.20^{\mathrm{a}}$ \\
\hline Т 11 & $4.50 \pm 0.15^{d}$ & $0.25 \pm 0.50^{\mathrm{e}}$ & $2.50 \pm 0.00^{f}$ & $0.20 \pm 0.10^{\mathrm{e}}$ & $0.09 \pm 0.10^{c}$ \\
\hline Т 12 & $1.93 \pm 2.10^{c}$ & $1.03 \pm 0.70^{b}$ & $7.50 \pm 0.08^{d}$ & $0.80 \pm 0.20^{b}$ & $0.44 \pm 0.30^{b}$ \\
\hline
\end{tabular}




$\begin{array}{llllll}\text { T 13 } & 1.13 \pm 1.10^{\mathrm{a}} & 0.65 \pm 2.10^{\mathrm{c}} & 4.00 \pm 0.60^{\mathrm{e}} & 0.50 \pm 0.30^{\mathrm{c}} & 0.23 \pm 0.20^{\mathrm{a}} \\ \text { T14 } & 1.02 \pm 0.00^{\mathrm{a}} & 0.63 \pm 0.00^{\mathrm{c}} & 4.10 \pm 0.06^{\mathrm{e}} & 0.40 \pm 2.00^{c d} & 0.77 \pm 0.10^{\mathrm{c}} \\ \text { T15 } & 0.75 \pm 0.20^{\mathrm{a}} & 0.50 \pm 0.40^{\mathrm{a}} & 3.50 \pm 0.20^{\mathrm{e}} & 0.38 \pm 1.10^{\mathrm{d}} & 0.14 \pm 0.33^{\mathrm{a}} \\ \text { T16 } & 0.71 \pm 0.80^{\mathrm{a}} & 0.40 \pm 0.15^{\mathrm{a}} & 3.60 \pm 0.10^{\mathrm{e}} & 0.40 \pm 0.30^{c d} & 0.18 \pm 1.30^{\mathrm{d}}\end{array}$

Means with the same letters are not significantly different within a column $(P \leq 0.05)$.

Key: T1- $3.1 \mathrm{mg}$ of glyphosate $/ \mathrm{ml}+P$. aeruginosa, T2- $7.2 \mathrm{mg} / \mathrm{ml}+P$. aeruginosa, T3- $14.4 \mathrm{mg} / \mathrm{ml}+P$. aeruginosa, T4- $3.1 \mathrm{mg} / \mathrm{ml}+B$. cereus, T5- $7.2 \mathrm{mg} / \mathrm{ml}+B$. cereus, T6- $14.4 \mathrm{mg} / \mathrm{ml}+B$. cereus, T7- $3.1 \mathrm{mg} / \mathrm{ml}+$ Mixed culture of $B$. cereus/ P. aeruginosa, T8- $7.2 \mathrm{mg} / \mathrm{ml}+$ mixed culture, T9- $14.4 \mathrm{mg} / \mathrm{ml}$ + Mixed culture, T10- unsprayed soil, T11- $P$. aeruginosa, T12- $B$. cereus, T13- mixed culture of $B$. cereus/ $P$. aeruginosa,T14- $3.1 \mathrm{mg} / \mathrm{ml}$ only, T15- $7.2 \mathrm{mg} / \mathrm{ml}$ only, T16- $14.4 \mathrm{mg} / \mathrm{ml}$ only.

\section{Discussion}

The potentials of Bacillus cereus and Pseudomonas aeruginosa were evaluated for their effectiveness in plant growth promotion in the screen house and field. The result showed that the treated seedlings were found to be comparably different from the untreated (control) ones in terms of plant height, maize girth and leaf area. The treated seeds did better than the untreated ones. This agrees with the findings of Parth and Bharatkumar, (2014) who reported a significant increase in plant growth parameters on mung bean plants inoculated with native isolates when compared with the control. Plant growth enhancement by bacteria may relate to the ability of the former to produce extensive root length, root development and rate of mineral and water uptake (Fanken et al., 2014). This increase in growth may be attributed to phytohormone production and solubilization of insoluble minerals due to increased phosphate and other mineral nutrients to the inoculated plant (Gyaneshwar et al., 2002).

Decreased plant height was observed at higher concentration of glyphosate. This reduced growth recorded at $14.4 \mathrm{mg} / \mathrm{ml}$ is twice the recommended dose and may be associated with the toxicity of the herbicide to the plant as well as its effect on the plant growth promoting abilities of the isolates. Results in this experiment agree with the findings of Michel et al. (2016) who revealed a reduced height and leaf area in maize plants exposed to over dose of glyphosate. Carvalho et al. (2013) reported a decrease in leaf area and plant height of coffee with increasing concentration of glyphosate.
Previous reports showed that glyphosate decreased plant height of faba beans and winter wheat (Petroczi et al., 2002). The result of maize height on the soil containing mixed culture of the isolate also agrees with the findings of Mines and Mohammed (2011) that rhizobacteria enhances growth in the absence and presence of herbicide. Ahemad and Khan (2011) observed inhibition of the functioning enzyme participating in different metabolic pathways of plant growth promoting traits and decline in other essential phytohormones under herbicide stress, leading to poor growth in plants. A reduction in growth of green gram plants following herbicide applications due to the adverse effect of the herbicide on the plant organ especially the nodules, which consequently diminishes nitrogen fixation, has been reported (Ahmed and Sagir., 2011), Such inhibitory effect following herbicide application might be due to the inhibition of the enzymes involved in growth and metabolism (Zablotowics and Reddy, 2004). The result of this study is also in line with the findings of Joyce et al. (2017) who observed a decrease $i \quad n$ the growth of maize on soil treated with overdose of glyphosate but no significant effect on the one treated with the recommended and half of the recommended dose. In contrast to the findings of this work, Velini et al. (2008) reported that the growths of maize, conventional soybeans and Eucalyptus were enhanced by $1.8-36 \mathrm{~g}$ /ha of glyphosate.

Effects of glyphosate and bacterial inoculants on the maize girth were also evaluated. The results showed no significant difference $(P \leq 0.05)$ in the 
size of girth at different concentration and time (WAP) on the plants inoculated with $P$. aeruginosa, $B$. cereus or both. The soil inoculated with $P$. aeruginosa recorded lower girth size at a concentration of $14.4 \mathrm{mg} / \mathrm{ml}$ glyphosate when compared to the lower concentration of $3.1 \mathrm{mg} / \mathrm{ml}$ and the control. These results are in line with the findings of Senarathne and Perera (2010) who reported no significant effect of different concentrations of glyphosate on the size of girth of coconut seedlings in nurseries. The results are however at variance with the findings of Muniru et al. (2017) that reported a significant difference in maize girth sprayed with different concentrations of post emergent herbicide after 9 weeks of spray. The results of the field studies showed no significant effects of glyphosate and microbial inoculants on the growth of the maize plants. The results of the effect of glyphosate and bacteria inoculants on heights of the maize plants showed that at 3 WAP, the plot inoculated with mixed culture of Bacillus cereus and $P$. aeruginosa recorded the highest plant height $(35.33 \mathrm{~cm})$ but least on the plot spiked with $14.4 \mathrm{mg} / \mathrm{ml}$ glyphosate $(18.85 \mathrm{~cm})$, while at 7 WAP, the highest height was recorded from the plot spiked with $3.1 \mathrm{mg} / \mathrm{ml}$ and inoculated with mixed culture of the isolates while the least was from the plot spiked with $14.4 \mathrm{mg} / \mathrm{ml}$ only. The plot inoculated with the mixed culture of the isolates also recorded the highest height (154.25 $\mathrm{cm}$ ) while the least was from the plot spiked with $7.2 \mathrm{mg} / \mathrm{ml}$. The results partly agree with the report of Michel et al. (2016) who revealed no significant difference at lower doses, with decrease in heights at higher doses when compared with the control. It is also in line with the findings of Samany et al. (2013) who recorded no significant effect on the growth of wheat after glyphosate application. The results of the number of leaves on the maize at different concentrations and time were also not significantly different $(P \leq 0.05)$ at different concentrations when compared to the control. This is also in line with the findings of Michel et al. (2016) and Labri et al. (2013) who also observed no significant difference in the number of leaves produced by plants at different concentrations of glyphosate when compared with control. It is at variance with the findings of Shaban et al. (1987) who reported an increase in the number of branches and leaves per plant in faba beans at high doses of glyphosate.

The results of the yield parameters showed that the stover weight of the maize from the plot inoculated with $P$. aeruginosa only was significantly higher than the control as well as others treated with different concentrations of glyphosate, while the plot treated with $7.2 \mathrm{mg} / \mathrm{ml}$ and Bacillus cereus recorded the highest ear weight and cob weight; greater number of cobs were observed in the plot treated with $P$. aeruginosa and $7.2 \mathrm{mg} / \mathrm{ml}$ of glyphosate. Joyce et al., (2017) reported that the yield parameters of maize sown in plots in which the herbicides had been applied at or below the manufacturer's recommended dose (2.11 ai/ha) were comparable to those of the control; and then significantly decreased in the plots in which the herbicides were applied in overdose. The application of primextra was observed to have a significant effect on the crop when it was applied at the required rate, more than when the herbicide was applied lower and higher than the required application rate (Enyong et al.,2013). This agrees with the finding of this study, and could be due to the adverse effect of the high concentrations of the herbicide (Yazdanpak et al, 2014). This is partly at variance with the studies which indicated that the use of herbicides results in higher yield, compared to the traditional manual method of weed control (Agahiu et al., 2011; Enyong et al., 2013)

In conclusion, this study has revealed the ability of these isolates to enhance the growth of maize under glyphosate stress. It has also provided an insight into the consequence of high dosage of glyphosate on the plant growth promoting abilities of the two isolates and for optim um performances of the isolates while using glyphosate. There is a need for farmers to stick to or use the herbicide below the recommended dose so as to reduce its deleterious effects to the plant growth promoting abilities of these isolates. 


\section{References}

Agahiu, A. E., Udensi, U. E., Tarawali, G., Okoye, B.C., Ogbuji, R.O and Baiyeri, K. P.( 2011). Assessment of weed management strategies and intercrop combinations on cassava yield in the middle belt of Nigeria. Afr. J. Agric. Research 6: $5729-5735$

Ahemad, M. and Khan, M.S. (2011). Plant growth promoting fungicide-tolerant rhizobium improves growth and symbiotic characteristics of lentil (Lens esculentus) in fungicide-applied soil. J. Plant Growth Regul. 10:10-11.

Akintokun A.K., Ezaka, E., Akintokun, P.O., Shittu, O.B and Taiwo, L.B.(2019). Isolation, Screening and Response of maize to plant growth promoting rhizobacteria inoculants. Scientia Agriculturae Bohemica 50:181-190

Beata E.M, James B.R, Pedro L.O.A, Machado CM, Elemo T, Gregory, W.M. (2006). Mid and near infrared spectroscopic assessment of soil compositional parameters and structural indices in two ferralsols. Spectroscopy letters 38: 721740.

Carvalho, L.B., Alves, P.L.C. and Duke, S.O. (2013). Hormesis with glyphosate depends on coffe growth stage. An Acad Bras Cienc. 85:813821.

Enyong, J. K., Ndaeyo, N.U., Ndon, B.A., Ugbe, L. A. and Akpan, E. A. 2013. Preliminary evaluation of effects of herbicide types and rates on growth and yield of cassava (Manihot esculenta Crantz). Intl J. Basic and Applied Sci. 2: 65 - 70.

Ezaka, E., Akintokun, A.K., Akintokun, P.O. and Taiwo, L.B.(2018). Glyphosate degradation by two plant growth promoting bacteria isolated from rhizosphere of maize, Microbiology Research Journal International, 26:1-11.

Fanken, H., Nguesseu, N.G., Ngo, N.L., and Etoa, F. (2014). Rock phosphate solubilizing bacteria and their effect on soyabean (Glycine max) growth under pot grown condition. Am J. Agric. For. 2:100-109.
Gyaneshwar, P., Naresh, G., Parekh, L. J and Poole, P.S. (2002). Role of soil micro organisms in improving plant nutrition. Plant Soil 245:8393.

IITA. (2001). International Institute of Tropical Agriculture, Ibadan, Oyo State. Annual report on maize production.

Joyce, C. B., Anthony, E.A. and Edache, B.O. (2017). Effects of applications of different rates of herbicides on growth and yield component of Zea mays L. Greener J. Agric. 7:32-38.

Michel, M. K., Nicolas, N.Y. and Juliane, F. (2016). Effects of soil treated glyphosate on growth parameters and chlorophyll content of maize(Zea mays $\mathrm{L}$ ) and bean (Phaseolus vulgaris L) plant. Braz. J. of Biol sci, 3:351-365.

Muniru, B., Olatunde, P.A and Rex, D.A. (2017). Evaluation of selected post emergence herbicides for weed management in maize at different agroecological zones of Nigeria. World J. of Agric. Res. 5:258-264.

Parth, V.B. and Bharatkumar, R.M.V. (2014). Screening and characterization of plant growth and health promoting rhizobacteria. Intl. J. Cur microbial. Applied sci. 3:139-155.

Petroczi, I.M., Mantuz, J. and Kotai, C.(2002). Study of pesticide side effects in winter wheat trials. Acta Biology 46:207-208.

Sarmamy, I., Khidir, S. M. and Abdul-ghany, O. (2013). Effects of some soil treated pesticides on growth characteristics of faba bean and wheat plants. IJETCAS 5:7-20.

Senarathine, S.H.S. and Perera, K.C. (2010). Impact of glyphosate on weed biomass and growth of coconut seedlings in nurseries. Cocos 19:51-56.

Shaban, S. A., El-Hattab, A. H., Hassan, E. A., Abo-Elsuoud, M. R. (1987). Recovery of faba bean (Vicia faba L.) plants as affected by glyphosate. J. Agron. Crop Sci. 158: 294- 303. 
Velini, E. D., Alves E., Godoy, M.C, Meschede, D. K, Souza R.T and Duke S. O. (2008). Glyphosate applied at low doses can stimulate plant growth. Pest manag. Sci. 64:489-96.

Yazdanpak, A., Amiri A., Faghihi, K, and Karimian, N.A. (2014). The residual effect of herbicides on the germination and early growth of shiraz wheat cultivar in the development of healthy agricultural crops. Am. Eurasian J. Agric. Environ. Sci. 14: $161-164$.

Zablotowicz, R. M. and Reddy, K. N. (2004). Impact of glyphosate on the Bradyrhizob-ium japonicum symbiosis with glyphosate-resistant transgenic soybean: a mini review. J. Environ. Qual. 33:825-831. 